\title{
PERAN APPROACHING TIME DALAM PENINGKATAN PELAYANAN JASA PEMANDUAN KAPAL DI PELABUHAN UTAMA TANJUNG PRIOK
}

\section{THE ROLE OF APPROACHING TIME ON PILOTAGE SERVICES AT THE PORT OF TANJUNG PRIOK}

\author{
Ika Citra Sari ${ }^{1}$, Ruddy Suwandi ${ }^{2}$, Arif Satria ${ }^{3}$, Deni Achmad Soeboer ${ }^{4}$ \\ ${ }^{1}$ Port, Shipping and Logistic Management \\ ${ }^{2}$ Pusat Kajian Sumberdaya Pesisir dan Lautan, Institut Pertanian Bogor \\ ${ }^{3}$ Fakultas Ekologi Manusia, Institut Pertanian Bogor \\ ${ }^{4}$ Stasiun Lapang Kelautan \\ Korespondensi: citraadiputera@gmail.com
}

\begin{abstract}
Approaching time is usually used as one of indicator on evaluating the successful of piloting'sservice level of ship in main port in Indonesia. However, in many main ports in some countries, this method is no longer used. This study is aimed to determine the significancy of approaching time as a standard in evaluating the piloting's service in Indonesia. The research has been conducted in the Port of Tanjung Priok, where involved the respondents of pilotage personnels, ship captains, helmsman, and also some retired pilotage personnels which formerly have worked as pilotage. The data were analized using AHP (Analytical Hierarchy Process), AHP will describe the problem as multi-factor complex into a structured and systematic so easy to understand. The results showedthat $56.59 \%$ of respondences agree the approaching time is still important as an indicator on evaluating the service of pilotage, while $43.41 \%$ of them thought that it needs more considerations to use the approaching time as an evaluation indicator. It is important to note approaching time since it is a measurable workface in a shipping port in conducting the piloting service. This is caused that the pilotages still depend on the availabilities of all tools such astug boat in which the quantity and its capacity must still be raised again.
\end{abstract}

Keyword: Analytical Hierarchy Process, approaching time, indicators, pilotage

\begin{abstract}
ABSTRAK
Approaching time merupakan salah satu indikator yang dipergunakan untuk mengukur keberhasilan kinerja pelayanan jasa pemanduan kapal di Indonesia. Saat ini di pelabuhan-pelabuhan besar dunia approacbing time tidak dijadikan sebagai indikator untuk mengukur kinerja jasa pemanduan kapal mereka. Penelitian ini bertujuan mengetahui sudah tepatkah penerapan approaching time sebagai salah satu ukuran standar kinerja pelayanan jasa pemanduan di Indonesia. Penelitian telah dilakukan di Pelabuhan Utama Tanjung Priok dengan responden yang meliputi para personel pandu, awak kapal tunda (nakhoda, KKM, juru mudi) dan pensiunan pandu yang pernah bekerja di Pelabuhan Utama Tanjung Priok. Metode analisis yang diterapkan untuk pengolahan data adalah AHP (Analytical Hierarchy Process), karena AHP akan menguraikan masalah multi faktor yang kompleks menjadi terstruktur dan sistematis sehingga mudah untuk dipahami. Hasil penelitian menunjukkan 56.59\% responden berpendapat approaching time dapat tetap dipertahankan sebagai tolak ukur kinerja jasa pemanduan; sisa responden (43.41\%) menganggap perlunya mengkaji ulang penerapan approaching time sebagai tolak ukur kinerja jasa pemanduan. Approaching time menjadi penting diperhatikan, karena merupakan hasil kerja terukur yang telah tercapai pada suatu pelabuhan dalam melaksanakan jasa pelayanan pemanduan kapal. Hal ini disebabkan, pandu sebagai personil yang menjalankan proses pemanduan kapal masih sangat tergantung pada fasilitas sarana dan prasarana alat bantu pemanduan kapal seperti kapal tunda, yang jumlah serta kapasitas dayanya masih harus ditingkatkan lagi.
\end{abstract}

Kata kunci: Analytical Hierarchy Process, approaching time, personel pandu, tolok ukur 


\section{PENDAHULUAN}

\section{Latar belakang}

Nakhoda membutuhkan bantuan seorang tenaga ahli, terutama apabila kapal yang dipimpinnya akan memasuki wilayah pelabuhan lain. Demi kepentingan keselamatan dan keamanan pelayaran serta kelancaran berlalu lintas di pelabuhan, Pemerintah menetapkan perairan wajib pandu dan perairan pandu luar biasa. Penetapan perairan wajib pandu disebabkan olehkegiatan bongkarmuatdipelabuhan serta lalu lintas yang padat di kolam pelabuhan, sehingga diwajibkan menggunakan jasa pelayanan pemanduan. Bagi pemanduan luar biasa tidak diwajibkan dilakukan pemanduan karena kondisi perairannya, apabila nakhoda memerlukan jasa pelayanan pemanduan dapat mengajukan permintaan fasilitas pemanduan atau melalui pengawas pemanduan. Masalah kelancaran, keamanan, keselamatan kapal yang dipandu adalah hal yang utama dalam pelaksanaan pemanduan kapal, karena akibat yang dapat ditimbulkan dari suatu kelalaian atas kegiatan pemanduan kapal dapat berpengaruh pada kelancaran lalu lintas kapal dalam pelabuhan, bahkan terhadap perairan dan lingkungannya (Haryono \& Setiono 2013).

Jasa pemanduan yaitu kegiatan pandu dalam membantu, memberikan saran dan informasi kepada nakhoda tentang keadaan perairan setempat agar navigasi pelayaran dapat dilaksanakan dengan selamat, tertib dan lancar demi keselamatan kapal dan lingkungan pelabuhan.

Peraturan Menteri Perhubungan tentang Pemanduan dan Penundaan Kapal No 57 Tahun 2015 Pasal 1 (4), pandu adalah pelaut yang memiliki keahlian di bidang nautika yang telah memenuhi persyaratan untuk melaksanakan pemanduan kapal. Personel pandu akan membantu nakhoda dalam memberikan nasihat (advisor), informasi serta petunjuk kepada nakhoda tentang keadaan perairan setempat yang artinya tanggung jawab kapal sepenuhnya tetap berada pada Nakhoda. Personel pandu juga mempunyai peranan yang sangat penting dalam menciptakan tingkat keselamatan kapal-kapal yang akan keluar masuk suatu pelabuhan, sekaligus memperlancar distribusi logistik nasional.

Jasa pelayanan pemanduan kapal merupakan pelayanan pertama dan terakhir yang diberikan kepada kapal yang akan singgah di suatu pelabuhan. Oleh karena itu hal ini menjadi sangat penting untuk terus meningkatkan kualitas pelayanannya.

Pengukuran standar kinerja pemanduan didasarkan pada standar lokal dan internasional (ISO standard). Pelabuhanpelabuhan besar di dunia mempergunakan zero accident dan zero waiting time for pilot service sebagai ukuran target keberhasilan pelayanannya sedangkan di Indonesia dalam menilai kinerja jasa pemanduannya mempergunakan approaching time (AT), waiting time (WT) dan zero accident.

Abdullah (2014) menyatakan faktor yang mempengaruhi approaching time yaitu jarak tempuh dari/ke lokasi sandar/lepas, tingkat kepadatan kapal di pelabuhan, tingkat kesulitan olah gerak, pandangan keliling dan faktor alam.

Pelabuhan Utama Tanjung Priok merupakan salah satu pelabuhan utama di Indonesia. Secara logika sebagai salah satu pelabuhan utama dengan tingkat kepadatan lalu lintas kapal yang semakin tinggi, maka personel pandu, sarana dan prasarana bantu pemanduan (kapal tunda, kapal pandu, kapal kepil) serta hal-hal yang berhubungan dengan peningkatan pelayanan pemanduan akan semakin ditingkatkan. Namun apa yang menjadi alasan pelabuhan di Indonesia, dalam hal ini Pelabuhan Utama Tanjung Priok masih menerapkan approaching time menjadi salah satu key performance indicator yang dipergunakan untuk mengukur kinerja jasa pelayanan pemanduannya sedangkan di pelabuhanpelabuhan besar dunia approaching time tidak dipergunakan untuk mengukur standar kinerja pelayanan mereka. Tujuan penelitian ini untuk menentukan apakah sudah tepat approaching time dijadikan sebagai salah satu standart kinerja jasa pelayanan pemanduan di Indonesia, karena untuk mendapatkan kualitas jasa pemanduan yang semakin baik diperlukan standar kinerja yang tepat bagi jasa pelayanan pemanduan di Indonesia.

\section{METODE PENELITIAN}

Penelitian dilakukan pada bulan September-November 2016 di Pelabuhan Utama Tanjung Priok khususnya di PT Jasa Armada Indonesia Unit Operasi Tanjung Priok. Responden pada penelitian ini berjumlah 29 orang yang meliputi para personel pandu, pensiunan pandu yang pernah bekerja di Pelabuhan Utama Tanjung Priok serta awak kapal tunda. Sumber data 
diperoleh dari data primer yaitu dari hasil pengolahan kuisioner dan wawancara mendalam (in-depth interview) dan data sekunder yang meliputi laporan gerakan kapal bulanan di Pelabuhan Tanjung Priok, data komposisi pandu di Pelabuhan Tanjung Priok, sarana dan prasarana bantu pemanduan yang meliputi komposisi kapal tunda, kapal pandu dan kapal kepil serta petunjuk teknis tata cara pemanduan kapal di Pelabuhan Tanjung Priok.

Metode analisis yang dipergunakan yaitu metode AHP (Analytical Hierarchy Process). AHP merupakan suatu proses yang dipergunakan dalam pengambilan kebijakan atau perumusan strategi prioritas. AHP pertama kali diperkenalkan oleh Thomas L Saaty pada tahun 1970-an. Pemilihan model keputusan ini karena AHP akan menguraikan masalah multi faktor yang kompleks menjadi terstruktur dan sistematis sehingga mudah untuk dipahami. Permasalahan tersebut dalam AHP disederhanakan dalam bentuk hirarki yang terdiri dari 3 komponen utama, yaitu tujuan dari pengambilan keputusan, kriteria penilaian dan alternatif pilihan.

Menurut Saaty (1993), hirarki didefinisikan sebagai suatu representasi dari sebuah permasalahan yang kompleks dalam suatu struktur multi level dimana level pertama adalah tujuan, yang diikuti level faktor, kriteria, sub kriteria, dan seterusnya ke bawah hingga level terakhir dari alternatif. Adanya hirarki membuat suatu masalah yang kompleks dapat diuraikan ke dalam kelompok-kelompoknya yang kemudian diatur menjadi suatu bentuk hirarki sehingga permasalahan akan tampak lebih terstruktur dan sistematis (Permadi 1992).

Metode AHP digunakan untuk menghitung tingkat kepentingan dari masing-masing indikator. Adapun tahapan yang dilakukan dalam AHP adalah:

1. Menentukan jenis-jenis kriteria yang menyebabkan approaching time.

2. Menyusun kriteria-kriteria tersebut dalam bentuk matriks berpasangan.

3. Menjumlah matriks kolom.

4. Menghitung nilai elemen kolom kriteria dengan rumus masing-masing elemen kolom dibagi dengan jumlah matriks kolom.

5. Menghitung nilai prioritas kriteria dengan rumus menjumlah matriks baris hasil langkah ke 4 dan hasilnya
5 dibagi dengan jumlah kriteria.

6. Menentukan alternatif-alternatif yang akan menjadi pilihan.

7. Menyusun alternatif-alternatif yang telah ditentukan dalam bentuk matriks berpasangan untuk masing-masing kriteria, sehingga akan ada sebanyak $\mathrm{n}$ buah matriks berpasangan antar alternatif.

8. Masing-masing matriks berpasangan antar alternatif sebanyak $\mathrm{n}$ buah matriks, masing-masing matriksnya dijumlah per kolomnya.

9. Menghitung nilai prioritas alternatif masing-masing matriks berpasangan antar alternatif dengan rumus seperti langkah 4 dan langkah 5. Prosedur penilaian perbandingan berpasangan dalam AHP, mengacu pada skor penilaian yang telah dikembangkan oleh Thomas L Saaty dicantumkan dalam Tabel 1.

10. Menguji konsistensi setiap matriks berpasangan antar alternatif dengan rumus masing-masing elemen matriks berpasangan pada langkah 2 dikalikan dengan nilai prioritas kriteria. Hasilnya masing-masing baris dijumlah, kemudian hasilnya dibagi dengan masing-masing nilai prioritas kriteria sebanyak a1, a2 ,a3 ,..., an.

11. Menghitung a max dengan rumus :

$$
\text { a } \max =\frac{\sum a}{n}
$$

12. Menghitung $\mathrm{CI}$ dengan rumus :

$$
\mathrm{CI}=\frac{a \max }{n-1}
$$

13. Menghitung CR dengan rumus :

$$
\mathrm{CR}=\frac{C I}{R C}
$$

Kondisi $\mathrm{CR}<0,1$, maka nilai perbandingan berpasangan pada matriks kriteria yang diberikan konsisten. Kondisi $\mathrm{CR}>0,1$, maka nilai perbandingan berpasangan pada matriks kriteria yang diberikan tidak konsisten. Nilai tidak konsisten, maka pengisian nilai-nilai pada matriks berpasangan pada unsur kriteria maupun alternatif harus diulang.

Struktur hirarki yang akan dipergunakan untuk penelitian ini dicantumkan dalam Gambar 1. 
Tabel 1. Skala perbandingan dalam AHP

\begin{tabular}{|c|c|c|}
\hline Nilai & Definisi & Penjelasan \\
\hline 1 & Sama penting & $\begin{array}{l}\text { Dua variable menyumbang sama besar pada sifat } \\
\text { itu }\end{array}$ \\
\hline 3 & Sedikit lebih penting & $\begin{array}{l}\text { Pengalaman dan pertimbangan sedikit menyo- } \\
\text { kong satu variabel atas yang lainya }\end{array}$ \\
\hline 5 & Jelas lebih penting & $\begin{array}{l}\text { Pengalaman dan pertimbangan dengan kuat me- } \\
\text { nyokong satu variabel diatas yang lainnya }\end{array}$ \\
\hline 7 & Sangat jelas penting lebih & $\begin{array}{l}\text { Satu variabel dengan kuat disokong dan domi- } \\
\text { nanya terlihat dalm praktek }\end{array}$ \\
\hline 9 & Mutlak lebih penting & $\begin{array}{l}\text { Bukti yang menyokong variabel satu atas varia- } \\
\text { bel lainnya memiliki tingkat penegasan tertinggi } \\
\text { yang mungkin menguatkan }\end{array}$ \\
\hline $2,4,6,8$ & $\begin{array}{l}\text { Nilai-nilai diantara dan per- } \\
\text { timbangan yang berdekatan }\end{array}$ & Kompromi diperlukan antara dua pertimbangan \\
\hline
\end{tabular}

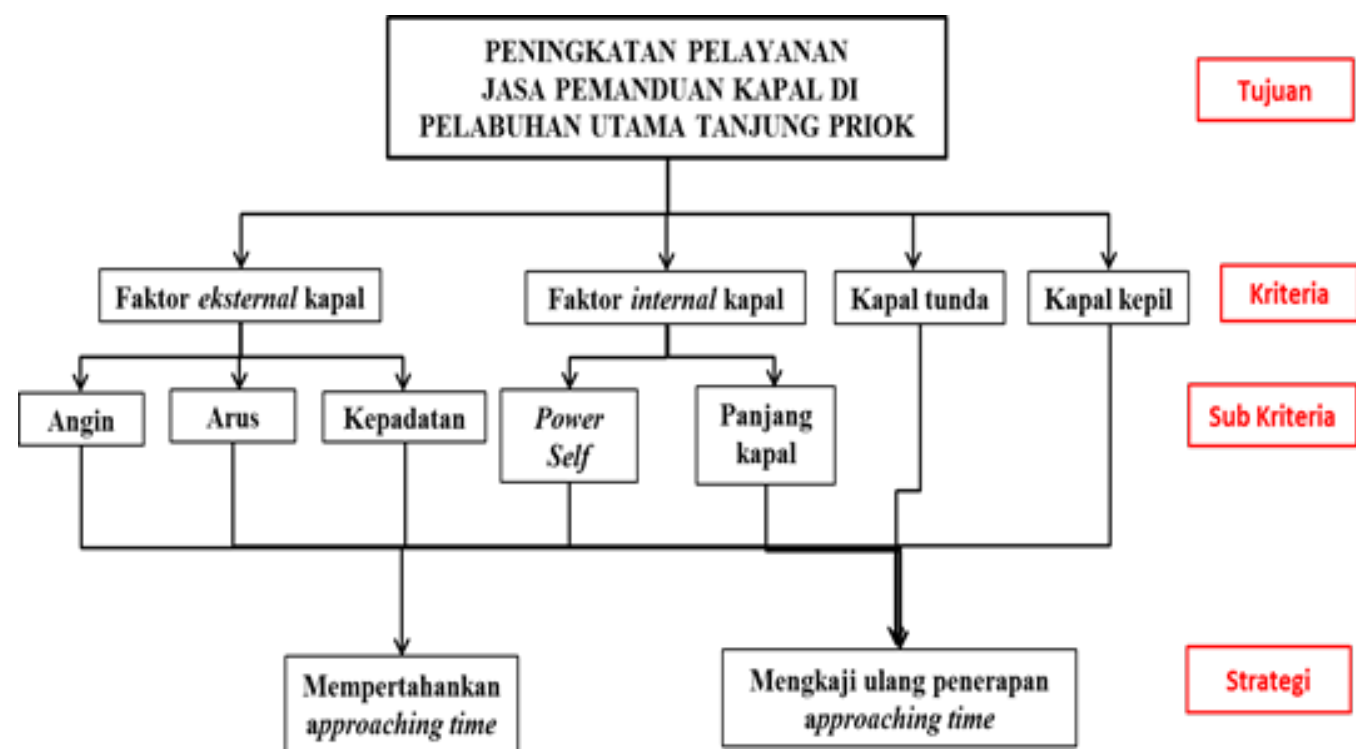

Gambar 1. Struktur hirarki AHP peningkatan jasa pemanduan di Pelabuhan Utama Tanjung Priok

\section{HASIL DAN PEMBAHASAN}

\section{Matriks perbandingan berpasangan untuk kriteria}

Hasil rekapitulasi data perbandingan berpasangan untuk masing-masing kriteria dengan 29 responden dapat dilihat pada Tabel 2, yang merupakan rataan geometrik dari hasil perbandingan kriteria untuk 29 responden yang mengisi kuesioner.

Tabel 2 menunjukkan bobot faktor eksternal lebih tinggi dari faktor internal yaitu 1.04 kalinya, sama seperti perbandingan terhadap kapal kepil yaitu 2.74 kalinya, sedangkan faktor eksternal memiliki nilai perbandingan 0.45 kalinya dari kapal tunda, artinya kepentingan kapal tunda lebih penting dibandingkan faktor eksternal. Perbandingan faktor internal 0.48 kalinya dari kapal tunda artinya kepentingan kapal tunda lebih penting dari faktor internal sedangkan faktor internal memiliki bobot kepentingan lebih besar 2.58 kalinya dari kapal kepil. Perbandingan antara kapal tunda lebih penting 3.96 kalinya dari kapal kepil, sehingga dari proses perhitungan AHP berdasarkan matriks pada Tabel 2 diperoleh hasil bobot persentase prioritas kepentingan yang dapat dilihat pada Tabel 3.

Berdasarkan tabel diatas, untuk seluruh responden diperoleh hasil bobot kriteria, kapal tunda memiliki skor tertinggi yaitu $45.10 \%$ artinya kapal tunda menjadi prioritas utama untuk peningkatan jasa pelayanan pemanduan di Pelabuhan Utama Tanjung Priok. Prioritas kedua yaitu faktor eksternal kapal dengan skor kepentingan sebesar 23\%. Prioritas ketiga yaitu faktor internal kapal dengan skor kepentingan 
sebesar $22.50 \%$ dan prioritas terakhir adalah kapal kepil sebesar $9.40 \%$. Pengujian konsistensi jawaban responden dapat dilihat dari nilai inconsistency sebesar 0.01, dimana nilai inconsistency kurang dari 0.1 artinya memenuhi syarat konsisten.

\section{Matriks perbandingan berpasangan untuk sub kriteria berdasarkan faktor eksternal}

Hasil rekapitulasi data perbandingan berpasangan untuk masing-masing kriteria dengan 29 responden dapat ditunjukkan pada Tabel 4, yang merupakan rataan geometrik dari hasil perbandingan kriteria untuk 29 responden yang mengisi kuesioner. Tabel 4 menunjukkan bobot sub kriteria faktor eksternal dengan perbandingan sub kriteria angin memiliki tingkat kepentingan yang lebih tinggi yaitu 2.97 kalinya dari sub kriteria arus dan perbandingan kepentingan sub kriteria angin memiliki tingkat kepentingan yang lebih tinggi dari sub kriteria kepadatan yaitu 1.81 kalinya. Hal ini menunjukkan bahwa angin memiliki tingkat kepentingan yang lebih tinggi dari arus dan kepadatan. Perbandingan tingkat kepentingan sub kriteria arus adalah 0.73 kalinya dari sub kriteria kepadatan artinya sub kriteria kepadatan memiliki tingkat kepentingan yang lebih tinggi dari sub kriteria arus, sehingga dari proses perhitungan AHP berdasarkan matriks pada Tabel 4 diperoleh hasil bobot persentase prioritas kepentingan yang dapat dilihat pada Tabel 5 .

Hasil pada sub kriteria berdasarkan kriteria faktor ekternal kapal yaitu faktor angin memiliki prioritas utama dengan skor tertinggi yaitu $53.20 \%$. Prioritas kedua yaitu faktor kepadatan dengan total skor sebesar $27.70 \%$ dan yang menjadi prioritas ketiga yaitu faktor arus dengan total skor sebesar $19.10 \%$. Pengujian konsistensi jawaban responden dapat dilihat dari nilai inconsistency sebesar 0.01, dimana nilai inconsistency kurang dari 0.1 artinya memenuhi syarat konsisten.

\section{Matriks perbandingan berpasangan untuk sub kriteria berdasarkan faktor internal}

Hasil rekapitulasi data perbandingan berpasangan untuk masing-masing kriteria dengan 29 responden dapat ditunjukkan pada Tabel 6, yang merupakan rataan geometrik dari hasil perbandingan kriteria untuk 29 responden yang mengisi kuesioner. Tabel 6 menunjukkan bobot sub kriteria faktor internal dengan perbandingan sub kriteria power self memiliki tingkat kepentingan yang lebih tinggi yaitu 1.1 kalinya dari sub kriteria panjang kapal, sehingga dari proses perhitungan AHP berdasarkan matriks pada Tabel 6 diperoleh hasil bobot persentase prioritas kepentingan yang dapat dilihat pada Tabel 7 .

Hasil pada sub kriteria berdasarkan kriteria faktor internal kapal yaitu power self memiliki prioritas utama dengan skor tertinggi yaitu $54.20 \%$. Prioritas kedua yaitu panjang kapal dengan total skor sebesar $47.60 \%$. Pengujian konsistensi jawaban responden dapat dilihat dari nilai inconsistency sebesar 0.02, dimana nilai inconsistency kurang dari 0.1 artinya memenuhi syarat konsisten.

\section{Matriks perbandingan berpasangan untuk strategi}

Hasil rekapitulasi data perbandingan berpasangan untuk masing-masing kriteria dengan 29 responden dapat ditunjukkan pada Tabel 8, yang merupakan rataan geometrik dari hasil perbandingan kriteria untuk 29 responden yang mengisi kuesioner. Tabel 8 menunjukkan bobot strategi dengan perbandingan mempertahankan approaching time memiliki tingkat kepentingan yang lebih tinggi yaitu 1.30 kalinya dari menghapus approaching time, sehingga dari proses perhitungan AHP berdasarkan matriks pada Tabel 8 diperoleh hasil bobot persentase prioritas kepentingan yang dapat dilihat pada Tabel 9 .

Hasil alternatif strategi yaitu mempertahankan approachig time menjadi prioritas utama dengan total skor sebesar $56.59 \%$ dan prioritas kedua yaitu mengkaji ulang penerapan approaching time sebesar $43.41 \%$. Pengujian konsistensi jawaban responden dapat dilihat dari nilai inconsistency sebesar 0.02, dimana nilai inconsistency kurang dari 0.1 artinya memenuhi syarat konsisten.

\section{Hasil AHP}

Hasil analisis data dengan metoda AHP ditunjukkan dalam Gambar 2. Berdasarkan hasil AHP secara vertikal untuk seluruh responden diperoleh hasil, kapal tunda memiliki skor tertinggi yaitu $45.1 \%$ artinya kapal tunda menjadi prioritas utama untuk peningkatan jasa pelayanan pemanduan kapal di Pelabuhan Utama Tanjung Priok. Operasional kapal pandu dan kapal tunda merupakan unsur utama dari pelayanan 
pemanduan, yang merupakan kegiatan awal serta akhir dari keseluruhan rangkaian kegiatan masuk dan keluar kapal, (Ardyana dan Isbandono 2015).

Jasa adalah setiap tindakan atau perbuatan yang dapat ditawarkan oleh suatu pihak kepada pihak lain yang pada dasarnya bersifat intangible (tidak berwujud fisik) dan tidak menghasilkan kepemilikan sesuatu (Kotler 2003). Berdasarkan definisi ini maka pelayanan di pelabuhan dikategorikan pada kegiatan jasa karena dalam pengusahaan pelabuhan terdapat beberapa kegiatan dan fungsi pelabuhan yaitu menunjang kelancaran, keamanan, ketertiban arus lalu lintas atau trafik (kapal, barang dan atau penumpang), menjaga keselamatan berlayar, tempat perpindahan intra dan atau antar moda (Gurning \& Hariyadi 2007) dimana kegiatan-kegiatan tersebut tidak menghasilkan produk yang berwujud fisik. Oleh karena itu, untuk menilai kinerja pelabuhan harus didasarkan pada aspek kualitas jasa. Kualitas jasa dimulai dari kebutuhan pelanggan dan berakhir pada kepuasan pelanggan serta persepsi positif terhadap kualitas jasa (Kotler 2000). Konsumen sebagai pihak yang menerima dan membeli pelayanan jasa, maka konsumen juga mempunyai penilaian terhadap kualitas jasa. Berdasarkan beberapa kajian Santos dan Boote (2003) mengklasifikasi ekspektasi pelanggan ke dalam sembilan hirarki ekspektasi pelanggan mulai dari ideal expectation (tingkat kinerja optimum atau terbaik yang diharapkan dapat diterima konsumen) sampai dengan harapan yang dipersepsikan paling buruk (worst imaginable expectation). Hasil pada sub kriteria dengan kriteria faktor ekternal kapal yaitu faktor angin memiliki prioritas utama dengan skor tertinggi yaitu 53.20\%. Cuaca akan menentukan aktivitas atau kegiatan penerimaan atau kecepatan bongkar muat yang sedang atau akan dilakukan oleh kapal di dermaga. Cuaca cerah pada umumnya tidak memiliki kendala bagi kapal untuk melakukan kegiatan bongkar muat di dermaga, karena tidak ada pengaruh dari alam (angin, badai, gelombang) dan sebaliknya kondisi cuaca yang kurang baik akan menghambat aktivitas kapal untuk melakukan bongkar muat, karena dapat menyebabkan gelombang tinggi atau angin kencang sehingga dapat membahayakan muatan dan para pekerjanya (Harmaini 2010).

Hasil pada sub kriteria dengan kriteria faktor internal kapal yaitu power self memiliki prioritas utama dengan skor tertinggi yaitu 54.20\%. Saat ini kapal sudah memiliki salah teknologi yang membantu kapal dalam melakukan manuver yaitu bow thruster. Bow thuruster adalah satu unit peralatan dalam kapal yang berfungsi untuk menggerakkan kapal ke samping (kanan maupun kiri). Alat ini berupa unit pendorong yang terdiri dari suatu propeller yang berada dalam satu terowongan (tunnel) melintang kapal dan dilengkapi dengan suatu alat bantu seperti motor hidrolik atau elektrik. Selama beroperasi, air dipaksa melalui terowongan itu untuk mendorong kapal menyamping ke starboard atau port sesuai keperluan kapal (Berliandy 2011).

Hasil alternatif strategi yaitu mempertahankan approaching time menjadi prioritas utama dengan total skor sebesar 56.59\%. Berdasarkan Keputusan Direktorat Jenderal Perhubungan Laut Nomor UM.002/38/18/DJPL-11 tanggal 15 Desember 2011 tentang Standar Kinerja Pelayanan Operasional Pelabuhan, approaching time adalah jumlah waktu terpakai untuk kapal bergerak dari lokasi labuh sampai ikat tali di tambatan atau sebaliknya. Approaching time menjadi penting diperhatikan, karena merupakan hasil kerja terukur yang telah tercapai pada suatu pelabuhan dalam melaksanakan jasa pelayanan pemanduan kapal. Berdasarkan hasil kerja tersebut, kita dapat mengevaluasi sejauh mana keberhasilan suatu pelabuhan dalam memberikan pelayanannya. Susilo (2010) menyatakan sebuah pelabuhan dengan kualitas kelas dunia harus mampu memberikan layanan yang cepat, aman dan terpercaya. 
Tabel 2. Rata-rata bobot kriteria

\begin{tabular}{lcrr}
\hline & Faktor Internal & Kapal Tunda & Kapal Kepil \\
\hline Faktor Eksternal & 1.04 & 0.45 & 2.74 \\
Faktor Internal & & 0.48 & 2.58 \\
Kapal Tunda & & & 3.96 \\
\hline
\end{tabular}

Tabel 3. Hasil persentase bobot kriteria

\begin{tabular}{lr}
\hline \multicolumn{1}{c}{ Kriteria } & Bobot Kriteria \\
\hline Faktor Eksternal & $23.00 \%$ \\
Faktor Internal & $22.50 \%$ \\
Kapal Tunda & $45.10 \%$ \\
Kapal Kepil & $9.40 \%$ \\
\hline \multicolumn{2}{c}{ Inconsistency $=0.01$} \\
\hline
\end{tabular}

Tabel 4. Rata-rata bobot kriteria

\begin{tabular}{|c|c|c|}
\hline & Arus & Kepadatan \\
\hline Angin & 2.97 & 1.81 \\
\hline Arus & & 0.73 \\
\hline
\end{tabular}

Tabel 5. Hasil persentase bobot sub kriteria berdasarkan faktor eksternal

\begin{tabular}{lr}
\hline \multicolumn{1}{c}{ Sub Kriteria } & Bobot Prioritas \\
\hline Angin & $53.20 \%$ \\
Arus & $19.10 \%$ \\
Kepadatan & $27.70 \%$ \\
\hline \multicolumn{2}{c}{ Inconsistency $=0.01$} \\
\hline
\end{tabular}

Tabel 6. Rata-rata bobot kriteria

\begin{tabular}{rr}
\hline & \multicolumn{2}{c}{ Panjang Kapal } \\
\hline Power Self & 1.10 \\
\hline
\end{tabular}

Tabel 7. Hasil persentase bobot sub kriteria berdasarkan faktor internal

\begin{tabular}{lr}
\hline \multicolumn{1}{c}{ Sub Kriteria } & Bobot Prioritas \\
\hline Power Self & $52.40 \%$ \\
Panjang Kapal & $47.60 \%$ \\
\hline \multicolumn{2}{c}{ Incosistensy $=0.02$} \\
\hline
\end{tabular}

Tabel 8. Rata-rata bobot kriteria

\begin{tabular}{ll}
\hline & $\begin{array}{l}\text { Mengkaji ulang } \\
\text { Penerapan approaching time }\end{array}$ \\
\hline Mempertahankan Approaching time & 1.30 \\
\hline
\end{tabular}

Tabel 9. Hasil persentase bobot sub kriteria

\begin{tabular}{cr}
\hline \multicolumn{1}{c}{ Strategi } & Priority \\
\hline Mempertahankan Approaching time & $56.60 \%$ \\
Mengkaji ulang penerapan Approaching time & $43.40 \%$ \\
\hline & \\
\hline
\end{tabular}




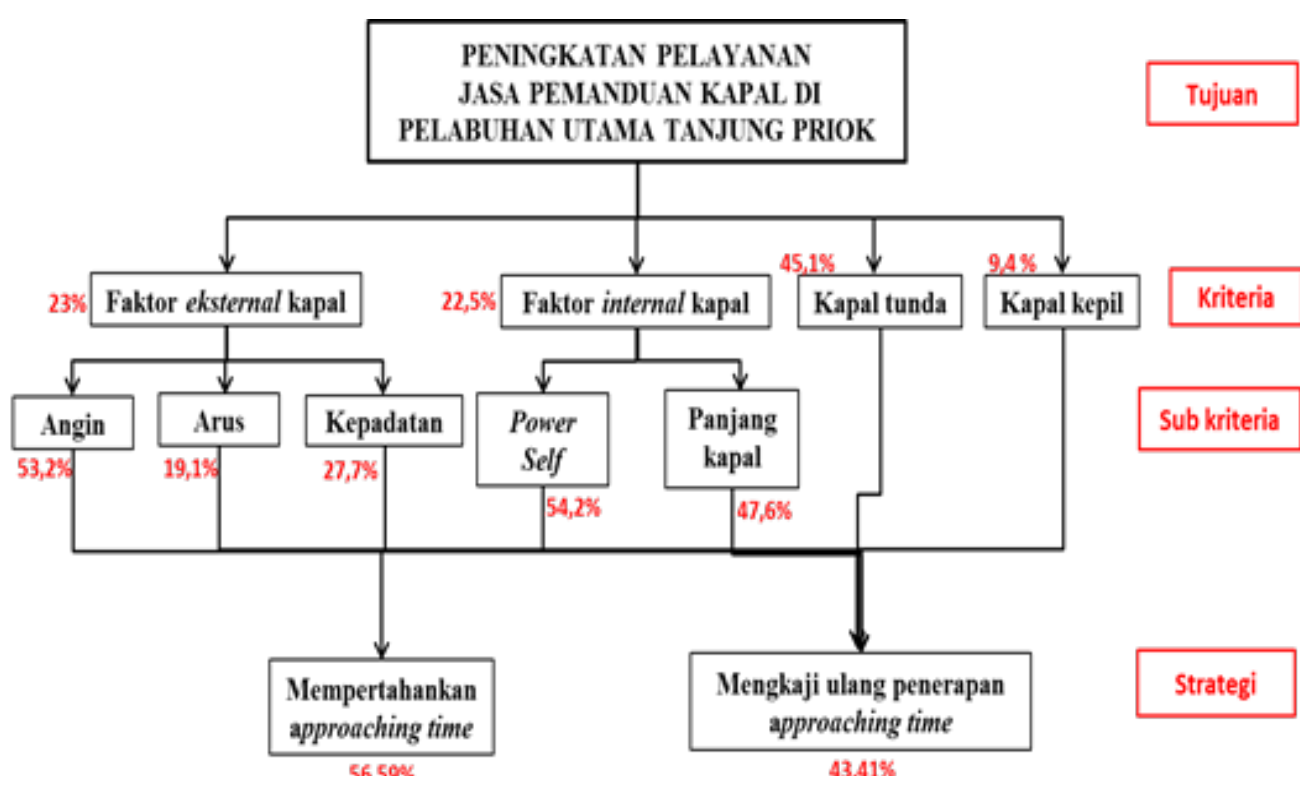

Gambar 2. Hasil analisis AHP

\section{KESIMPULAN DAN SARAN}

\section{Kesimpulan}

Appraoching time di Pelabuhan Utama Tanjung Priok berdasarkan analisis AHP perlu dipertahankan sebagai salah satu key performance indicator bagi jasa pelayanan pemanduan kapal, hal ini disebabkan oleh pandu sebagai personil yang menjalankan proses pemanduan kapal masih sangat tergantung pada fasilitas sarana dan prasarana alat bantu pemanduan kapal seperti kapal tunda, yang jumlah serta kapasitas dayanya masih harus ditingkatkan lagi.

\section{Saran}

Berdasarkan hasil analisis diatas, diketahui bahwa seorang personel pandu dalam memberikan jasa pelayanan pemanduan kapal sangat bergantung pada fasilitas sarana dan prasarana alat bantu pemanduan kapal, sehingga diperlukan penelitian lanjutan tentang aspek yang akan menjadi penentu keberhasilan jasa pelayanan pemanduan kapal di suatu pelabuhan, yaitu menghitung rasio perbandingan antara jumlah kapal yang masuk, personil pandu serta fasilitas sarana dan prasarana alat bantu pemanduan kapal (kapal tunda, kapal pandu, kapal kepil).

\section{DAFTAR PUSTAKA}

Abdullah E. 2014. Brief history pemanduan kapal di Indonesia: Kajian historis dengan analisis normatif. Yogyakarta. Deepublish.

Ardyana M, Isbandono P. 2015. Pengaruh kualitas pelayanan kapal terhadap kepuasan penggunajasa PT. Pelabuhan Indonesia III (Persero) Cabang Tanjung Perak (Studi pada jasa pemanduan kapal). Jurnal Universitas Negeri Surabaya. Vol 3 No 7. Halaman 3-15.

Berliandy N. 2011. Perhitungan modulus dan perencanaan konstruksi tambahan yang sesuai pada pemasangan "bow thuster". Politeknik Perkapalan Negeri Surabaya.[Skripsi]. Surabaya: Institut Teknologi Sepuluh Nopember.

Gurning, Haryadi. E. 2007. Manajemen bisnis pelabuhan. APE Publishing. Surabaya.

Harmaini W. 2010. Analisis faktor-faktor yang mempengaruhi waktu tunggu kapal di Pelabuhan Tanjung Emas Semarang. [Tesis]]. Semarang: Program Pascasarjana, Universitas Dipenegoro.

Haryono, Setiono BA. 2013. Sistem operasional pelayanan pemanduan terhadap keselamatan kapal di pt pelabuhan indonesia III (persero) cabang tanjung perak surabaya. Jurnal Ketatalaksanaan Pelayaran Niaga. Vol 2 No 2. Halaman 131-135. 
Kotler P, (2000). Manajemen pemasaran. PT. Prenhallindo, Jakarta.

Kotler P. (2003). Marketing management. 11 th edition, Prentice Hall, New

Pemerintah RI. 2015. Peraturan Menteri Perhubungan Nomor 57 Tahun 2015 tentang Pemanduan dan Penundaan Kapal. Jakarta (ID): Menteri Perhubungan.

Permadi B. 1992. AHP. Pusat Antar Universitas- Studi Ekonomi Universitas Indonesia. Jakarta.

Saaty TL. 1993. Pengambilan keputusan bagi para pemimpin, proses hirarki analitik untuk pengambilan keputusan dalam situasi yang kompleks. Jakarta. Pustaka Binama Pressindo.
Santos J, Boote J. 2003. A theoritical exploration and model of consumer expectation, post-purchase effective stages and effective behaviour. Journal of Consumer Behaviour. Vol. 3. No.2. Pp. 142-156.

Surat Keputusan. 2011. Surat Keputusan Direktorat Jenderal Perhubungan Laut No. UM.002/38/18/DJPL-1 1 tentang Standar Kinerja Pelayanan Operasional Pelabuhan

Susilo H. 2010. Improving vessel service performance by optimizing pilot and tug services: the case of The Port of Tanjung Priok, Indonesia [tesis]. Rotterdam(ID). Erasmus University Rotterdam. 